\title{
Historical summer distribution of the endangered North Atlantic right whale (Eubalaena glacialis): a hypothesis based on environmental preferences of a congeneric species
}

Sophie Monserrat

Maria G. Pennino

Tim D. Smith

Randall R. Reeves

Christine N. Meynard

Virginia Institute of Marine Science

See next page for additional authors

Follow this and additional works at: https://scholarworks.wm.edu/vimsarticles

Part of the Environmental Sciences Commons, and the Marine Biology Commons

\section{Recommended Citation}

Monserrat, Sophie; Pennino, Maria G.; Smith, Tim D.; Reeves, Randall R.; Meynard, Christine N.; Kaplan, David M.; and Rodrigues, Ana S.L., Historical summer distribution of the endangered North Atlantic right whale (Eubalaena glacialis): a hypothesis based on environmental preferences of a congeneric species (2015). Diversity and Distributions, 21(8), 925-937.

DOI: $10.1111 /$ ddi.12314

This Article is brought to you for free and open access by the Virginia Institute of Marine Science at W\&M ScholarWorks. It has been accepted for inclusion in VIMS Articles by an authorized administrator of W\&M ScholarWorks. For more information, please contact scholarworks@wm.edu. 


\section{Authors}

Sophie Monserrat, Maria G. Pennino, Tim D. Smith, Randall R. Reeves, Christine N. Meynard, David M. Kaplan, and Ana S.L. Rodrigues 


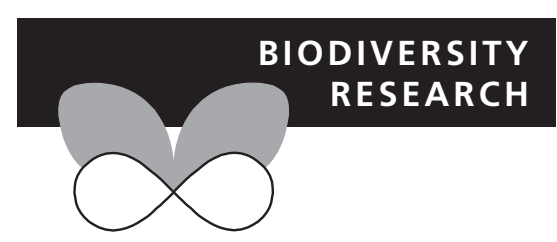

\title{
Historical summer distribution of the endangered North Atlantic right whale (Eubalaena glacialis): a hypothesis based on environmental preferences of a congeneric species
}

\author{
Sophie Monsarrat ${ }^{1}$, Maria G. Pennino ${ }^{2}$, Tim D. Smith ${ }^{3}$, Randall R. Reeves ${ }^{4}$, \\ Christine N. Meynard ${ }^{5,6}$, David M. Kaplan ${ }^{2,6}$ and Ana S. L. Rodrigues ${ }^{1}$
}

${ }^{1}$ CEFE UMR 5175, CNRS, Université de Montpellier, Université Paul-Valéry Montpellier, EPHE - CNRS, 1919 route de Mende, 34293 Montpellier Cedex 5,France,

${ }^{2}$ Institut de Recherche pour le Développement (IRD), UMR EME 212, Exploitation, Filières et Gouvernance, Avenue Jean Monnet, CS 30171, 34203 Sète Cedex, France, ${ }^{3}$ World Whaling History, Redding, CA, USA, ${ }^{4}$ Okapi Wildlife Associates, Hudson, QC, Canada, ${ }^{5}$ INRA, UMR CBGP (INRA/IRD/Cirad/Montpellier SupAgro), Campus International de Baillarguet, CS 30016, F-34988 Montferriersur-Lez Cedex, France, ${ }^{6}$ Virginia Institute of Marine Science, College of William \& Mary, PO Box 1346, Gloucester Point, VA 23062 USA

Correspondence: Sophie Monsarrat, Centre d'Ecologie Fonctionnelle et Evolutive (CEFE UMR 5175) - CNRS, 1919 route de Mende, 34293 Montpellier Cedex 5, France

E-mail: sophie.monsarrat@cefe.cnrs.fr

\section{ABSTRACT}

Aim To obtain a plausible hypothesis for the historical distribution of North Atlantic right whales (NARWs) (Eubalaena glacialis) in their summer feeding grounds. Previously widespread in the North Atlantic, after centuries of hunting, these whales survive as a small population off eastern North America. Because their exploitation began before formal records started, information about their historical distribution is fragmentary.

Location North Atlantic and North Pacific oceans.

Methods We linked historical records of North Pacific right whales (E. japonica; from 19th-century American whaling logbooks) with oceanographic data to generate a species distribution model. Assuming that the two species have similar environmental preferences, the model was projected into the North Atlantic to predict environmental suitability for NARWs. The reliability of these predictions was assessed by comparing the model results with historical and recent records in the North Atlantic.

Results The model predicts suitable environmental conditions over a wide, mostly offshore band across the North Atlantic. Predictions are well supported by historical and recent records, but discrepancies in some areas indicate lower discriminative ability in coastal, shallow-depth areas, suggesting that this model mainly describes the summer offshore distribution of right whales.

Main conclusions Our results suggest that the summer range of the NARW consisted of a relatively narrow band (width $c .10^{\circ}$ in latitude), extending from the eastern coast of North America to northern Norway, over the Grand Banks of Newfoundland, south of Greenland and Iceland, north of the British Isles and in the Norwegian Sea. These results highlight possibilities for additional research both on the history of exploitation and on the current summer distribution of this species. In particular, better survey coverage of historical whaling grounds could help inform conservation efforts for this endangered species. More generally, this study illustrates the challenges and opportunities in using historical data to understand the original distribution of highly depleted species.

\section{Keywords}

Boosted regression trees, Eubalaena, historical distribution, right whale, species distribution models, whaling. 


\section{INTRODUCTION}

The North Atlantic right whale (NARW, Eubalaena glacialis) is a migratory species that feeds during the summer at high latitudes and migrates in the winter to calve in temperate coastal waters (Kenney et al., 2001). It is thought to have occurred previously as at least two populations (eastern and western Atlantic), although genetic analyses suggest they were not genetically differentiated (Rosenbaum et al., 2000b). Its commercial exploitation spanned over a thousand years, first by the Basques (Aguilar, 1986), then by the Dutch, English, Americans and other nationalities, as one of the most desirable targets of the 17th- to 19th-century whaling industry (Reeves et al., 2007). By 1750, NARWs were considered commercially extinct (Allen, 1908), but as the few remaining individuals continued to be opportunistically taken by whalers, the species became close to biological extinction before it was given full legal protection in 1935 (Reeves et al., 2007). Today, it is classified as endangered by the International Union for Conservation of Nature's Red List of Threatened Species (Reilly et al., 2012). There are currently around 500 right whales in the western North Atlantic (Pettis, 2013). In the eastern Atlantic, they are considered functionally extinct, with only a few records in the past 50 years (Reilly et al., 2012).

Understanding the historical pre-whaling distribution of NARWs can shed light on the impact of past hunting and on the potential for recovery now that the main historical threat has been eliminated. However, given the ancient history of exploitation, data on this species' historical distribution are very fragmented, with ancient observations plagued by taxonomic and spatial uncertainty. As we go back in time, it becomes more difficult to identify records to species, as a combination of less detail and fuzzier whale taxonomy (Romero, 2012). Older records also often have little geographic precision, particularly those corresponding to summer occurrences. Indeed, whereas right whale exploitation in the winter mainly targeted females and calves in calving bays or along their coastal migration routes, summer whaling was not necessarily coastal. With methods for accurately measuring longitude at sea only available from the late 18th century, earlier offshore records are scarce. Even today, a bias remains towards coastal occurrences, with the bulk of monitoring effort on the eastern North American coast (Winn et al., 1986; Pettis, 2013; Whitt et al., 2013).

Correlative species distribution models (SDMs) can be generated from relatively simple distributional data combined with environmental information to produce a geographic description of the potential distribution of a species (Guisan \& Zimmermann, 2000; Guisan \& Thuiller, 2005; Elith \& Leathwick, 2009). Given their wide applicability, they have been described as the main predictive tool in ecology (Dawson et al., 2011; Bellard et al., 2012). In a conservation context, they can help identify priority areas for additional sampling of rare species (e.g. Engler et al., 2004; Guisan et al., 2006) or support conservation planning efforts
(Rondinini et al., 2006). SDMs have even been used specifically to guide management decisions affecting threatened whale populations (e.g. Keller et al., 2012; Mannocci et al., 2013; Bombosch et al., 2014; Gowan \& Ortega-Ortiz, 2014), sometimes on the basis of historical exploitation data (Torres et al., 2013). SDMs can be extrapolated across space (e.g. for predicting the potential distributions of invasive species; Peterson \& Vieglais, 2001; Ficetola et al., 2007), across time (e.g. for predicting range shifts under future climate scenarios; Araújo et al., 2005; Thuiller et al., 2005; Garcia et al., 2012) and even across species (e.g. to identify areas likely to harbour still undescribed species; Raxworthy et al., 2003).

The North Pacific right whale (NPRW, Eubalaena japonica) was also nearly driven to extinction by whaling, but its exploitation history is quite different. Despite some ancient whaling (Omura, 1986; Huelsbeck, 1988; Lee \& Robineau, 2004), the bulk of its exploitation occurred in relatively recent times, mainly in the mid-19th century (Josephson et al., 2008). Whaling took place across all its summer range, as American pelagic whalers explored the entire North Pacific. This particular episode of the history of whaling is well documented in the logbooks of American whaling ships (Smith et al., 2012), which thus provide a unique snapshot of the summer distribution of this species prior to its severe depletion.

These two species of right whales have a similar feeding behaviour, being both slow cruisers and specialist copepods filter feeders (Kenney, 2009), and share the same body morphology in adaptation to this particular diet (Woodward et al., 2006). In fact, for lack of evidence of significant differences, they were long considered a single species (Rice, 1998) and only recently distinguished through genetic analyses (Rosenbaum et al., 2000a; Sasaki et al., 2005). Phylogenetically related species often share the same ecological traits that affect how their distributions relate to environmental conditions (Wiens et al., 2010). Historical occurrence data for the NARW are too deficient to generate a basin-wide SDM. But if these two species share similar environmental preferences, data from the well-documented historical summer distribution of the NPRW can inform the little-known historical feeding grounds of the North Atlantic species.

Here, we predict the potential summer distribution of NARWs from a SDM incorporating environmental data and whaling records of NPRWs, assuming that the two species select the same type of environments. We then investigate how informative such predictions are by discussing whether they are supported by historical records in the North Atlantic.

\section{METHODS}

\section{Historical records of NPRWs}

Distribution records of NPRWs were obtained from 19thand early 20th-century logbooks kept aboard American offshore whaling ships (Maury, 1852; Townsend, 1935; Smith 
et al., 2012). Logbooks provide information on the date, location and species of whales seen or caught, as well as information on the days when none were reported. We examined records of NPRW presence and absence in summer (June-September) north of $20^{\circ} \mathrm{N}$, obtained from a sample of these logbooks (Smith et al., 2012). The dataset included c. 46,000 point records, including c. 4400 presences, between 1819 and 1904 (91\% of presence records from 1840 to 1850 ). Point records were gridded at a $1^{\circ} \times 1^{\circ}$ resolution, excluding cells with fewer than three observations to minimize the effect of false absences (Appendix S4 in Supporting Information). We tallied the number of observations of right whales and the number of observations where no right whales were reported. The sampling effort was 2176 grid cells, of which 611 were presences. See Appendix S1 for details.

\section{Environmental data}

During the summer months, right whales are actively engaged in feeding, and their distribution is believed to be mostly driven by the distribution of their prey, mainly copepods (Nemoto, 1970; Murison \& Gaskin, 1989; Mayo \& Marx, 1990). No dataset is currently available on the distribution of copepods at a global scale, but other oceanographic and topographic variables correlated to their distribution can be used (Rutherford et al., 1999; Friedlaender et al., 2006; Gregr \& Coyle, 2009).

We considered three climate variables - sea surface temperature (SST) (Norberg \& DeAngelis, 1997; Rutherford et al., 1999; Gregr \& Coyle, 2009), mixed layer depth (MLD) (Baumgartner \& Mate, 2003) and net primary productivity (NPP) (Norberg \& DeAngelis, 1997) - and three bathymetric variables - depth (DEPTH), slope (SLOPE) and distance to land (LANDDIST) (Hamazaki, 2002; Kaschner et al., 2006; Gregr, 2011; Torres et al., 2013). They were selected for being known to be correlated with the presence of right whales and/or copepods in summer (see Appendix S2). SST, MLD and NPP were averaged over the summer months (June-September) to capture the environmental conditions encountered during the main feeding period of NPRWs (Clapham et al., 2004). A long-term climatology was obtained by averaging SST and MLD over almost the entire 20th century (1900-92) and for NPP, which relies on more recent satellite data, over the period 1998-2007. Environmental data were aggregated at a $1^{\circ} \times 1^{\circ}$ resolution, using the 'raster' package (Hijmans, 2014) in R 3.0.2 ( $\mathrm{R}$ Development Core Team, 2013) to match the occurrence data.

\section{Species distribution modelling}

We used boosted regression trees (BRT, Elith et al., 2008) to combine environmental data with NPRW historical records to generate predictions of the environmental suitability for right whales in the North Atlantic. BRTs are based on classification trees, avoiding assumptions regarding variable distributions and optimizing model predictions through iterative bootstrapping. They are able to fit complex nonlinear relationships between predictors and the response variable (Elith et al., 2008) and have been shown to perform among the best when evaluating presenceabsence classification rates (Elith et al., 2006). Model parameters were selected to optimize the model using the 'caret' (Kuhn, 2008) and 'dismo' (Hijmans et al., 2013) packages in R. Fitted functions and relative influence of each variable, measured by the number of times this variable is selected for tree splitting (Elith et al., 2008), are presented in Appendix S3. Predictions of environmental suitability from the BRT were mapped on a $1^{\circ} \times 1^{\circ}$ grid in the North Pacific and the North Atlantic, by assigning a probability value to each cell based on its environmental values and the model's fitted functions. Before predicting into new areas, we eliminated cells with environmental values outside the range used to calibrate the models. The envelope of predicted presence was defined by applying a threshold which maximizes the sum of sensitivity and specificity (defined, respectively, as the proportion of accurately predicted absences/presences) (Jiménez-Valverde \& Lobo, 2007). Statistics on classification rates were then calculated to check on the predictive ability of the model within the calibration area by performing a fivefold cross-validation with a training and test dataset (a random selection of, respectively, $75 \%$ and $25 \%$ of the whaling data). The area under the receiver operator curve (AUC) (Pearce \& Ferrier, 2000) and the true skill statistics (TSS) (Allouche et al., 2006) were used to evaluate the model in this context (Appendix S3).

To test the extent to which the modelling assumptions affect the results, we also generated a SDM using a generalized additive model (GAMs; Hastie \& Tibshirani, 1986). Results are similar to those of the BRT model (see Appendix S4) and are not further discussed.

\section{Historical records of NARWs}

We reviewed the literature for confirmed or likely records of NARWs up to 1950, known or strongly suspected to have occurred between June and September. We concentrated on secondary sources reviewing the history of whaling by the main people known to have exploited right whales in the North Atlantic (Spanish and French Basques, Norse, Americans, English and Dutch), complemented by selected primary sources. We focused on records for which there was high confidence in species identification and high spatial precision (close or within $1^{\circ}$ ), but we have also included records with some taxonomic ambiguity (in particular, risk of confusion with bowhead whales Balaena mysticetus) as well as some records for which location was less precise. For further context, we also mapped recent records (post-1950) outside the main areas where the species is currently found. Data were entered into a database capturing each record's location, time, spatial/taxonomic uncertainty and sources. 
The resulting dataset is not of sufficient quality for a quantitative validation of the model's predictions in the North Atlantic. It was therefore used in a qualitative validation, contextualized by broader information on the history of whaling across the North Atlantic.

\section{RESULTS}

\section{Historical records of NPRWs}

Records of NPRW presence or absence were widely distributed across space, with a bias in sampling effort towards exploited whaling grounds and corridors connecting whaling grounds and main ports (e.g. Hawaii) (Fig. 1a). As shown by previous authors (Maury, 1852; Clapham et al., 2004; Gregr, 2011; Smith et al., 2012), whaling records indicate that NPRWs were historically concentrated in the summer in five main areas: the Gulf of Alaska, the south-eastern Bering sea, east of Kamchatka and the Kuriles, the Sea of Okhotsk and the Sea of Japan (Fig. 1b).

\section{Species distribution model}

The BRT fitted the data very well, explaining $67.2 \%$ of the deviance. An AUC value of 0.93 illustrates its good discrimination ability, that is the ability to correctly distinguish between occupied and unoccupied sites. The TSS value of 0.74 indicates a good agreement between the predicted and observed values. The BRT prediction was mostly driven by SST, NPP and MLD (respectively $43.1 \%, 23.4 \%$ and $13.5 \%$ of relative influence). The fitted functions indicated that the suitable feeding habitat for the NPRW was characterized by a surface temperature comprised between 5 and $15{ }^{\circ} \mathrm{C}$, NPP above $500 \mathrm{mg} \mathrm{C} \mathrm{m}^{-2}$ day $^{-1}$ and MLD $<20 \mathrm{~m}$ (Fig. S1). DEPTH and LANDDIST contributed, respectively, to $10.9 \%$ and $9.0 \%$ of the model. SLOPE contributed to $<5 \%$ to the model and was removed from the analysis.
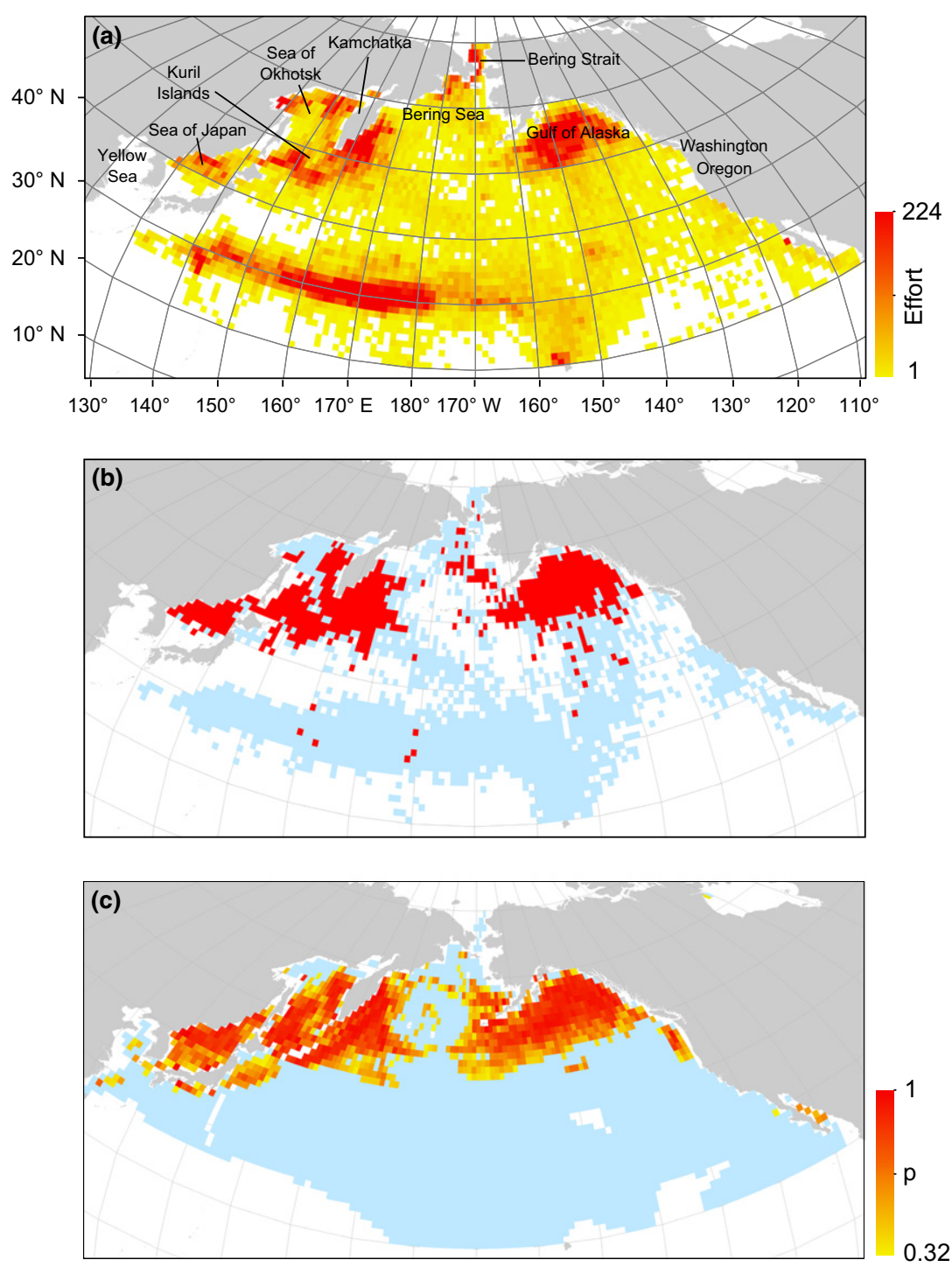

Figure 1 Historical data and model predictions in the North Pacific. (a) Sampling effort (measured as number of days when whalers were present in each cell according to 19th-century American whaling records) and geographic locations mentioned in the text. Effort was concentrated in the main whaling grounds for: sperm whales, around $30^{\circ} \mathrm{N}$; bowhead whales near the Bering Strait; and North Pacific right whales (NPRWs) in the Gulf of Alaska, east of Kamchatka, in the Sea of Okhotsk and in the Sea of Japan. (b) Historical distribution of NPRWs in the summer months (JuneSeptember), based on the whaling records. Data include both presence (red, where right whales were seen or caught) and absence records (blue, cells visited by whalers, but where no right whales were reported in the examined logbooks); white cells were not visited. (c) Predicted environmental suitability from a species distribution model fitted to the historical records. Shades of red indicate progressively higher suitability as predicted by the BRT models (above the $P=0.32$ threshold); blue cells correspond to areas where the species is predicted as absent; and white cells are areas for which no reliable predictions can be made. All data are presented on a $1^{\circ} \times 1^{\circ}$ grid in Bonne projection (standard parallel: $30^{\circ} \mathrm{N}$; central meridian: $\left.170^{\circ} \mathrm{W}\right)$. BRT, boosted regression trees. 


\section{Model predictions}

In the North Pacific (Fig. 1c), the model predicts high environmental suitability in a wide band across the northern extent of the basin, including all the whaling grounds but extending somewhat into a few other areas such as coastal Oregon and Washington States (USA) and the Yellow Sea.

In the North Atlantic, high environmental suitability is predicted in a wide continuous band extending from the eastern coast of North America (north of Virginia) to northern Norway (Fig. 2b). A few small pockets of high suitability were predicted around the Iberian Peninsula and in the northern Mediterranean Sea.

The species' potential presence envelope was defined in both basins to encompass cells with a predicted environmental suitability superior to a threshold $P=0.32$ (Fig. 2c). Areas in the North Atlantic for which no predictions could be made (i.e. with environmental conditions that were not adequately sampled by whaling records in the North Pacific; Appendix S3) include a patch east of Greenland as well as most of the Arctic regions, the Baltic Sea and the southern North Sea.

\section{Historical records of NARWs}

We found a total of 145 pre-1950 records, generally related to whaling activities and spanning a period of nearly 400 years (Table S2; Figs 2c and S3). These included 19 records for which species identity was not certain and 33 for which the location was only approximate. We also recorded and mapped 30 recent records (post-1950) outside the main current summer grounds (Table S3; Figs 2c and S4). Both historical and recent records cover a wide area across the North Atlantic.

\section{DISCUSSION}

We found good - but not perfect - agreement between the model's predictions (Fig. $2 b$ ) and the spatial extent of the historical records of the NARW (Fig. 2c). Both suggest that this species' historical feeding grounds extended across the North Atlantic, in a wide band from eastern North America to northern Norway, over the Grand Banks of Newfoundland, south and east of Greenland's Cape Farewell, south of Iceland, north of the British Isles and in the Norwegian Sea. This distribution pattern was mainly driven by cold temperatures, high productivity and low MLD.

Before discussing in more detail the extent to which the historical records support the model's predictions, we discuss key assumptions and caveats of our study that must be taken into consideration (also see Appendix S6).

\section{Assumptions and caveats}

Species distribution models represent the realized distribution of a species at a given time and place (Peterson et al., 2011), not differentiating among the factors limiting species distribution (such as prey availability, presence of competitors or dispersal limitations). This calls for caution when interpreting the results of models transferred across species and across temporal or geographical scenarios (Randin et al., 2006; Sinclair et al., 2010).

The model we have generated is only informative of the historical distribution of the NARW if this species' environmental requirements are similar to those of the NPRW. Given this strong assumption, the model's predictions must be interpreted as a hypothesis for - rather than as a reconstruction of - the historical distribution of the NARW. As previously discussed, the species' similarities in ecology and morphology justify that we explore this hypothesis. The main drivers of our prediction (SST, NPP and MLD) are consistent with those found in previous studies on the distribution of right whales (Baumgartner \& Mate, 2003; Gregr, 2011; Torres et al., 2013), reinforcing our assumption that right whales' distributions are generally driven by the same mechanisms.

The North Pacific whaling records are an exceptional dataset for developing a SDM. They can nonetheless include a number of false absences and false presences, as a result of biases (in sampling effort across space and time) and errors (in location and in species' identifications). We attempted to reduce these by analysing only cells with a reasonable sampling effort and by reducing sources of confusion with bowheads (Appendix S1). Nonetheless, we were unable to correct for the poor representation of shallow-depth data in the NPRW records (given that they correspond to offshore whaling operations) and its potential effects on the model's discriminative power in shallow-depth areas.

Our analysis is based on a geographic extrapolation from the North Pacific to the North Atlantic. We restricted predictions to the environmental envelope sampled by whalers in the Pacific Ocean to ensure that areas where we predict high environmental suitability are represented in the dataset used to calibrate the model, reducing one of the main sources of uncertainty under predictions of new scenarios (Zurell et al., 2009). We were, however, unable to control for other potential differences between basins (e.g. in prey availability, in the interactions between oceanographic conditions) which might limit the transferability of the statistical correlation found in one ocean basin into the other one (Randin et al., 2006). Process-based models combining behavioural and environmental factors could lead to a better understanding of the underlying processes driving right whales distribution (Palacios et al., 2013) but would require extensive physiological and behavioural information that are difficult to gather for these rare species.

By fitting the model using occurrence data mainly from the mid-19th century (1840-50) and environmental data from the 20th century (MLD and SST 1900-92; NPP 19982007), we necessarily assumed that the environmental spatial structure of the data has remained unchanged. Climatic variation, both longer-term directional changes (e.g. warming since the end of the Little Ice Age; Mann et al., 2008) and shorter-term cycles (e.g. El Niño Southern Oscillation, 

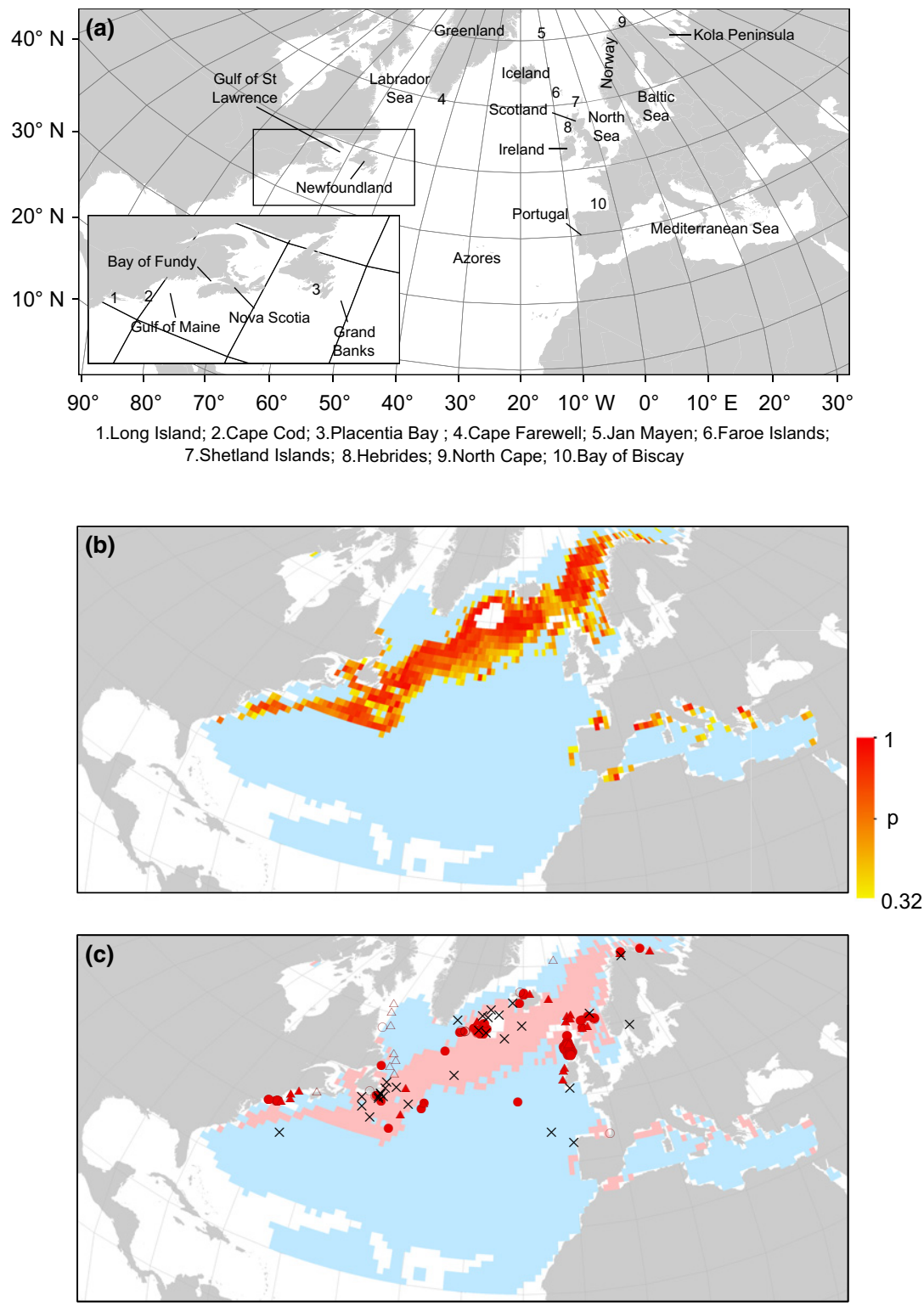

Figure 2 Model predictions and historical data in the North Atlantic. (a) Map of the North Atlantic indicating place names mentioned in the text. (b) Predicted historical distribution of the North Atlantic right whale in the summer months (June-September) based on a species distribution model (BRT) fitted to whaling records for the North Pacific right whale and extrapolated geographically into the Atlantic. Shades of red indicate progressively higher environmental suitability as predicted by the model (above the $P=0.32$ threshold); blue cells correspond to areas where the species is predicted as absent; and white cells are areas for which no reliable predictions can be made. (c) Historical records, obtained by reviewing the literature for confirmed or likely records from June to September. The area shaded in pink corresponds to the envelope of predicted presence as mapped in (b) (presented to facilitate comparisons with b). Symbols correspond to 142 historical (pre-1950) records from 1583 to 1935, distinguishing those for which there is higher (red symbols) or lower (open symbols) confidence in the species' identity and those for which there is higher (circles) or lower (triangles) precision in location. In addition, the map includes 26 recent (post-1950) records outside the main summer grounds (black crosses). See Figs S3 and S4, and Tables S2 and S3 for details on each record. All data are presented on a $1^{\circ} \times 1^{\circ}$ grid in Bonne projection (standard parallel: $30^{\circ} \mathrm{N}$, central meridian: $\left.20^{\circ} \mathrm{W}\right)$. BRT, boosted regression trees.

Nicholls, 2008; Pacific Decadal Oscillation, Mantua \& Hare, 2002), is known to affect the distribution of marine species (e.g. Evans \& Bjørge, 2013) and may therefore affect the results of our analyses. However, the use of occurrence data collected throughout the 19th century and of environmental data obtained by averaging long-term climatology is likely to mitigate these effects, by retaining the strong, persistent, seasonal signals in the data (Gregr, 2011). Furthermore, in a previous study facing a similar challenge, Gregr (2011) found that a review of climatic reconstructions did not reveal major differences in the North Pacific climate between the mid-19th and the 20th centuries. 
The NARW historical records we compiled constitute the most comprehensive dataset currently available on the historical summer occurrence of this species. Yet, it is biased spatially (towards coastal areas, where whales were more accessible) and temporally (towards a recent period when records became more detailed, despite the species being rarer) and plagued by geographic imprecision (location is only approximate for $23 \%$ of records) and by taxonomic uncertainty (for $13 \%$ of records). These limitations preclude the use of these data in a quantitative validation of the model's predictions. Instead, we discuss qualitatively, region by region, the extent to which the historical (Table S2) and recent (Table S3) records either support or contradict the model's predictions (Figs 2c, S3 and S4), keeping in mind the strengths and limitations of both the data and the model.

We place this discussion within the broader background of the history of whaling in each region, which provides additional records at the regional scale (too imprecise to map) and insights into whaling effort that contextualize the records in each region. Moving from west to east across the Atlantic, we discuss in particular the few instances where the model and records disagree.

\section{Comparison between the model predictions and species records in the North Atlantic}

The model predicts an area of suitable habitat for NARWs off the eastern coast of the United States south of Cape Cod, supported by a few historical records from coastal whaling operations, as well as by recent records (NOAA-NEFSC, 2013).

North of Cape Cod, the model predicts suitable areas over the continental slope, but absence in the shelf areas (Gulf of Maine, Nova Scotia; no predictions for the Bay of Fundy). The records show little evidence of historical presence of right whales in summer along this coast (Reeves et al., 1999, 2002) and therefore present no major contradiction to the model predictions. However, both the model predictions and the historical records disagree with today's known distribution of NARWs, as this shelf area appears to be the main region where right whales currently concentrate in the summer (NOAA-NEFSC, 2013; Wikgren et al., 2014). This discrepancy likely results from the model's poor capacity to discriminate habitat in shallow waters (having been calibrated mainly with deep waters data; Fig. S1). But the scarcity of historical records also raises the possibility that this region might not have been as important historically this species, at least in relative terms, as it is today.

The model predicts a broad suitable area over and around the Grand Banks of Newfoundland, well supported by 18thcentury American whaling records (e.g. specifically referring to right whaling 'east of the Grand Banks'; Reeves \& Mitchell, 1986; and an earlier map of an 'abandoned' right whale ground in this general area; Clark 1887).
Historical and recent records also support the predictions of suitable habitat around the coast of Newfoundland and into the Gulf of Saint Lawrence. This region was well known to 16th- and 17th-century Basque whalers (Ciriquiain-Gaiztarro, 1961; Du Pasquier, 2000), but studies of the history of Basque whaling have focused on the northern Gulf of Saint Lawrence and Strait of Belle Isle (Barkham, 1974), with recent genetic studies indicating that bowheads were the focus (McLeod et al., 2008). But a 1538 report explicitly mentions whaling in south-east Newfoundland (Hakluyt, 1889), suggesting Basques exploited a wider area. Furthermore, historical references to separate summer and early winter whaling seasons suggest that both right whales and bowheads were targeted (but see McLeod et al., 2008).

A few historical records off northern Labrador are not supported by the model's predictions. However, species identity is uncertain for these records, which may plausibly correspond to bowheads, as this falls within the historical summer distribution of this species (Reeves et al., 1983). These records are therefore not a main challenge to the model's predictions.

A large area of high suitability is predicted south and south-east of Greenland, and south of Iceland. This includes the area known as the Cape Farewell Ground, where the historical presence of NARW is well supported by 19th-century American whaling records (Reeves \& Mitchell, 1986; Reeves et al., 2007). Basque whalers might have also caught right whales in this region during the 17th-18th centuries ( $\mathrm{Du}$ Pasquier, 2000). Furthermore, it is one of the few regions outside the eastern North American coast where NARWs have been recorded recently (Brown et al., 2007; Mellinger et al., 2011).

Predictions of presence off the southern coast of Iceland are supported by historical records, including some too imprecise to map ('about 50 miles to the west of that island', 'to the south-east of Iceland'; Collett, 1909; Du Pasquier, 2000). Several historical records off north-western Iceland seem to contradict the model's predicted absence (Lindquist, 1994; Edvardsson \& Rafnsson, 2006) but are in fact located within coastal cells where the model makes no predictions.

The Faroe Islands are well within the model's predicted area of historical presence, whereas the Shetlands are at the edge. Historical records indicate that right whales were taken off both archipelagos (Jonsgård, 1977).

Model predictions are contradicted by a concentration of historical records off the Hebrides and Ireland, a region predicted as unsuitable. This may again reflect the model's limited predictive capacity in shallow-depth regions. However, these records correspond to a specific whaling period, whose well-documented details (Haldane, 1905, 1907; Collett, 1909; Thompson, 1918) suggest an exceptional rather than regular presence of NARWs. Indeed, despite ongoing whaling effort (for fin and sei whales, Balaenoptera physalus and B. borealis), no right whales were reported off the British Isles between 1889 and 1904. In contrast, 63 were captured between 1905 and 1914, with 'several hundred' seen in 1908 
(Collett, 1909). This is reminiscent of concentrations occasionally observed in other pelagic fisheries, associated with exceptional oceanic conditions (e.g. Fonteneau et al., 2008). If an oceanic anomaly is the explanation for these records, they would in any case be impossible to predict with a model based on a long-term averaged climatology.

The model predicts suitable habitat in the Norwegian Sea and around the North Cape. This is supported by a few coastal whaling records, reflecting a 17th- to 18th-century right whaling ground (see Smith et al., 2006 for a review). Du Pasquier (2000) collected > 200 records of Basque whaling trips to 'Norway' that we could not map but which could have plausibly corresponded to whaling in this area. There are also two recent records for this region.

Outside the main band of predicted suitability, the model predicts a few patches of suitable habitat around the Iberian Peninsula and in the northern Mediterranean Sea. Of these, only in the Gulf of Biscay we found an historical summer record, but in an area where whaling historically took place in the winter (Aguilar, 1986; Azpiazu, 2000; Barkham, 2000). These areas are known to have high concentrations of zooplankton that support feeding populations of whales (e.g. of fin whales Balaenoptera physalus in the north-western Mediterranean Sea; Notarbartolo-Di-Sciara et al., 2003), but given the lack of support for the predicted presence of NARWs, we cannot rule out the possibility that the model overestimates the historical distribution of the foraging grounds for this species.

Conversely, there are a few records outside the area predicted by the model. A historical record off Jan Mayen (of low species certainty) and a recent record in the Baltic (where the model makes no predictions) are not major challenges to the model. But a historical record north of the Azores and two recent records to the northwest of the Iberian Peninsula contradict the model's predicted absence. These are reminiscent of a few isolated records in the central North Pacific (between $20^{\circ}$ and $40^{\circ} \mathrm{N}$, also outside the area predicted by the model; Fig. 1a), where their rarity despite high whaling effort (for sperm whales) suggests that they correspond to migrating individuals rather than regular feeding grounds.

\section{CONCLUSIONS}

The generally high agreement between the model predictions and the historical records suggests that the model based on NPRW whaling data is informative of the historical summer distribution of NARWs. If so, this distribution extended across the North Atlantic in a wide continuous band from eastern North America to northern Norway, including substantial areas of offshore habitat outside known records.

Nonetheless, there are discrepancies between the model's predictions and the historical data that point to potential limitations. In particular, failure to predict both the current summer grounds off North America and the historical whaling grounds off the British Isles suggests lack of predictive power in shallow-depth, shelf regions. Additionally, predictions in areas for which we have no evidence that they were historical NARW foraging grounds (e.g. in the Mediterranean) suggest further limitations in the model. The model's predictions should therefore be mainly seen as a hypothesis for the summer offshore distribution of the NARW.

Our results pave the way for additional research and monitoring with potential implications for the conservation of the endangered NARW. Indeed, the model predictions raise hypotheses that should be further explored in two ways. Firstly, exploration of the surviving historical record in the light of these results can help to clarify the history of the exploitation of this species. In particular, the model's results suggest that more attention is warranted to whaling records in and around Newfoundland, in offshore grounds around the Grand Banks, in south of Greenland/Iceland and in the Norwegian Sea. Secondly, the model highlights regions potentially used by today's populations. Indeed, nearly all recent records outside the main known summer grounds fall within the area predicted as suitable by the model, suggesting that these records correspond to purposeful visits to suitable feeding areas rather than vagrancy or extra limit straying. With many individuals not accounted for every year in the intensive surveys at the main grounds (Hamilton et al., 2007), identification of other regularly used areas is key to guiding strategic conservation efforts. Passive acoustic methods such as those used by Mellinger et al. (2011) may be a cost-effective option for sampling such areas.

More broadly, our analysis illustrates the challenges and opportunities of combining historical and environmental data to improve understanding of the original distribution of highly depleted species. Because the quality of the historical record generally declines strongly as we go back in time, relatively recent population declines are much better documented than ancient ones, which are often underestimated or even forgotten (Pauly, 1995). Nonetheless, the spatial heterogeneity of historical human impacts creates opportunities for using information from the more recently impacted, better-known regions to fill gaps in knowledge elsewhere, using SDMs to extrapolate between the two. The challenges are particularly significant for species that have suffered ancient impacts across their entire range. For some of these, extrapolation from ecologically similar phylogenetically related species can be used to generate hypothesis that add depth to the fragmentary historical record. As understanding of the processes that drive species' spatial distribution improves, the informative value of these extrapolations across space and taxa will increase, making historical data even more useful.

\section{ACKNOWLEDGEMENTS}

The MORSE project funded this project (Agence Nationale de la Recherche, CEP\&S 2011 - Project ANR-11-CEPL-006). This paper benefited from discussions with members of the CESAB (Center for Synthesis and Analysis of Biodiversity) PELAGIC project, financed by the Fondation pour la 
Recherche sur la Biodiversité (FRB) and the Fondation TOTAL. This paper is Contribution No. 3435 of the Virginia Institute of Marine Science, College of William \& Mary. We acknowledge two anonymous referees and the handling editor for insightful and constructive comments.

\section{REFERENCES}

Aguilar, A. (1986) A review of old Basque whaling and its effect on the right whales (Eubalaena glacialis) of the North Atlantic. Reports of the International Whaling Commission, Special Issue 10, 191-199.

Allen, J.A. (1908) The North Atlantic right whale and its near allies. Bulletin of the AMNH; v. 24, article 18. Bulletin American Museum of Natural History, XXIV, 277-329 (+plates).

Allouche, O., Tsoar, A. \& Kadmon, R. (2006) Assessing the accuracy of species distribution models: prevalence, kappa and the true skill statistic (TSS). Journal of Applied Ecology, 43, 1223-1232.

Araújo, M.B., Pearson, R.G., Thuiller, W. \& Erhard, M. (2005) Validation of species-climate impact models under climate change. Global Change Biology, 11, 15041513.

Azpiazu, J.A. (2000) Balleneros Vascos en el Cantabrico. Ttarttalo Argitaletxea, Donostia.

Barkham, S.H. (1974) The Spanish province of Terranova. Canadian Archivist, 2, 73-83.

Barkham, M. (2000) La industria pesquera en el País Vasco peninsular al principio de la Edad Moderna: ¿una edad de oro? Itsas Memoria. Revista de Estudios Maritimos del Pais Vasco, 3, 29-75.

Baumgartner, M.F. \& Mate, B.R. (2003) Summertime foraging ecology of North Atlantic right whales. Marine Ecology Progress Series, 264, 123-135.

Bellard, C., Bertelsmeier, C., Leadley, P., Thuiller, W. \& Courchamp, F. (2012) Impacts of climate change on the future of biodiversity: biodiversity and climate change. Ecology Letters, 15, 365-377.

Bombosch, A., Zitterbart, D.P., Van Opzeeland, I., Frickenhaus, S., Burkhardt, E., Wisz, M.S. \& Boebel, O. (2014) Predictive habitat modelling of humpback (Megaptera novaeangliae) and Antarctic minke (Balaenoptera bonaerensis) whales in the Southern Ocean as a planning tool for seismic surveys. Deep Sea Research Part I: Oceanographic Research Papers, 91, 101-114.

Brown, M.W., Kraus, S.D., Slay, C.K.E.A. \& Garrison, L.P. (2007) Surveying for discovery, science, and management. The urban whale: North Atlantic right whales at the crossroads (ed. by S.D. Kraus and R.M. Rolland), pp. 105-137. Harvard University Press, Cambridge, MA, USA.

Ciriquiain-Gaiztarro, M. (1961) Los vascos en la pesca de la ballena. Editorial Txertoa, San Sebastian, Spain.

Clapham, P., Good, C., Quinn, S., Reeves, R.R., Scarff, J.E. \& Brownell, R.L. Jr (2004) Distribution of North Pacific right whales (Eubalaena japonica) as shown by 19th and 20th century whaling catch and sighting records. Journal of Cetacean Research and Management, 6, 1-6.

Clark, A.H. (1887) Map of the world on Mercator projection showing the extent and distribution of the present and abandoned whaling grounds. Fisheries and Fishery Industries of the United States, pp. Plate 183. Government Printing Office, Washington, DC.

Collett, R. (1909) A few notes on the whale Balaena glacialis and its capture in recent years in the North Atlantic by Norwegian whalers. Proceedings of the Zoological Society of London, 7, 91-97.

Dawson, T.P., Jackson, S.T., House, J.I., Prentice, I.C. \& Mace, G.M. (2011) Beyond predictions: biodiversity conservation in a changing climate. Science, 332, 53-58.

Du Pasquier, T. (2000) Les Baleiniers Basques. Editions S.P.M, Paris.

Edvardsson, R. \& Rafnsson, M. (2006) Basque whaling around Iceland: archeological investigation in Strákatangi, Steingrímsfjörður. Náttúrustofa Vestfjarða (Natural History Institute of Vestfirðir) \& Strandagaldur ses, Bolungarvík.

Elith, J. \& Leathwick, J.R. (2009) Species distribution models: ecological explanation and prediction across space and time. Annual Review of Ecology, Evolution, and Systematics, 40, 677-697.

Elith, J., Graham, C.H., Anderson, R.P. et al. (2006) Novel methods improve prediction of species' distributions from occurrence data. Ecography, 29, 129-151.

Elith, J., Leathwick, J.R. \& Hastie, T. (2008) A working guide to boosted regression trees. Journal of Animal Ecology, 77, 802-813.

Engler, R., Guisan, A. \& Rechsteiner, L. (2004) An improved approach for predicting the distribution of rare and endangered species from occurrence and pseudo-absence data. Journal of Applied Ecology, 41, 263-274.

Evans, P.G. \& Bjørge, A. (2013) Impacts of climate change on marine mammals. MCCIP Science Review, 2013, 134148.

Ficetola, G.F., Thuiller, W. \& Miaud, C. (2007) Prediction and validation of the potential global distribution of a problematic alien invasive species - the American bullfrog: predicting the success of invasions. Diversity and Distributions, 13, 476-485.

Fonteneau, A., Lucas, V., Tewkai, E., Delgado, A. \& Demarcq, H. (2008) Mesoscale exploitation of a major tuna concentration in the Indian Ocean. Aquatic Living Resources, 21, 109-121.

Friedlaender, A.S., Halpin, P.N., Qian, S.S., Lawson, G.L., Wiebe, P.H., Thiele, D. \& Read, A.J. (2006) Whale distribution in relation to prey abundance and oceanographic processes in shelf waters of the Western Antarctic Peninsula. Marine Ecology Progress Series, 317, 297-310.

Garcia, R.A., Burgess, N.D., Cabeza, M., Rahbek, C. \& Araújo, M.B. (2012) Exploring consensus in 21st century projections of climatically suitable areas for African vertebrates. Global Change Biology, 18, 1253-1269. 
Gowan, T.A. \& Ortega-Ortiz, J.G. (2014) Wintering habitat model for the North Atlantic Right Whale (Eubalaena glacialis) in the southeastern United States. PLoS ONE, 9, e95126.

Gregr, E.J. (2011) Insights into North Pacific right whale Eubalaena japonica habitat from historic whaling records. Endangered Species Research, 15, 223-239.

Gregr, E.J. \& Coyle, K.O. (2009) The biogeography of the North Pacific right whale (Eubalaena japonica). Progress in Oceanography, 80, 188-198.

Guisan, A. \& Thuiller, W. (2005) Predicting species distribution: offering more than simple habitat models. Ecology Letters, 8, 993-1009.

Guisan, A. \& Zimmermann, N.E. (2000) Predictive habitat distribution models in ecology. Ecological Modelling, 135, 147-186.

Guisan, A., Broennimann, O., Engler, R., Vust, M., Yoccoz, N.G., Lehmann, A. \& Zimmermann, N.E. (2006) Using niche-based models to improve the sampling of rare species. Conservation Biology, 20, 501-511.

Hakluyt, R. (1889) Principal navigations, voyages, traffiques and discoveries of the English nation (Vol. XII. America. Part I.). E\&G Goldsmith, Edinburgh.

Haldane, R.C. (1905) Notes on whaling in Shetland 1904. Annals of Scottish Natural History, 54, 53-56.

Haldane, R.C. (1907) Whaling in Scotland. Annals of Scottish Natural History, 61, 10-15.

Hamazaki, T. (2002) Spatiotemporal prediction models of cetacean habitats in the mid-western North Atlantic ocean (from Cape Hatteras, North Carolina, USA to Nova Scotia, Canada). Marine Mammal Science, 18, 920-939.

Hamilton, P.K., Knowlton, A.R. \& Marx, M.K. (2007) Right whales tell their own stories: the photo-identification catalog. The urban whale: North Atlantic right whales at the crossroads (ed. by S.D. Kraus and R.M. Rolland), pp. 75104. Harvard University Press, Cambridge, MA, USA.

Hastie, T. \& Tibshirani, R. (1986) Generalized additive models. Statistical Science, 1, 297-310.

Hijmans, R.J. (2014) raster: geographic data analysis and modeling. R package version 2.2-12.

Hijmans, R.J., Phillips, S.J., Leathwick, J.R. \& Elith, J. (2013) dismo: species distribution modeling. $\mathrm{R}$ package version 0.9 3.

Huelsbeck, D.R. (1988) Whaling in the precontact economy of the central Northwest coast. Arctic Anthropology, 25, 115 .

Jiménez-Valverde, A. \& Lobo, J.M. (2007) Threshold criteria for conversion of probability of species presence to eitheror presence-absence. Acta Oecologica, 31, 361-369.

Jonsgård, A. (1977) Tables showing the catch of small whales (including minke whales) caught by Norwegians in the period 1938-75, and large whales caught in different North Atlantic waters in the period 1868-1975. Reports of the International Whaling Commission, 27, 413-426.

Josephson, E.A., Smith, T.D. \& Reeves, R.R. (2008) Depletion within a decade: the American 19th-century North Pacific right whale fishery. Oceans past: management insights from the history of marine animal populations (ed. by D.J. Starkey, P. Holm and M. Barnard), pp. 109-132. Earthscan, London, UK.

Kaschner, K., Watson, R., Trites, A.W. \& Pauly, D. (2006) Mapping world-wide distributions of marine mammal species using a relative environmental suitability (RES) model. Marine Ecology Progress Series, 316, 285-310.

Keller, C., Garrison, L., Baumstark, R., Ward-Geiger, L. \& Hines, E. (2012) Application of a habitat model to define calving habitat of the North Atlantic right whale in the southeastern United States. Endangered Species Research, 18, 73-87.

Kenney, R.D. (2009) Right whales Eubalaena glacialis, E. japonica, and E. australis. Encyclopedia of marine mammals (ed. by W.F. Perrin, B. Würsig and J.G.M. Thewissen), pp. 962-972. London.

Kenney, R.D., Mayo, C.A. \& Winn, H.E. (2001) Migration and foraging strategies at varying spatial scales in western North Atlantic right whales: a review of hypotheses. Journal of Cetacean Research and Management, 2, 251260.

Kuhn, M. (2008) Building predictive models in $\mathrm{R}$ using the caret package. Journal of Statistical Software, 28, 1-26.

Lee, S.-M. \& Robineau, D. (2004) Les cétacés des gravures rupestres néolithiques de Bangu-dae (Corée du Sud) et les débuts de la chasse à la baleine dans le Pacifique nordouest. L'Anthropologie, 108, 137-151.

Lindquist, O. (1994) Whales, dolphins and porpoises in the economy and culture of peasant fishermen in Norway, Orkney, Shetland, Faeroe Islands and Iceland, ca. 900-1900 $A D$, and Norse Greenland, ca 1000-1500 AD. Faculty of Arts, University of St Andrews, Scotland, UK.

Mann, M.E., Zhang, Z., Hughes, M.K., Bradley, R.S., Miller, S.K., Rutherford, S. \& Ni, F. (2008) Proxy-based reconstructions of hemispheric and global surface temperature variations over the past two millennia. Proceedings of the National Academy of Sciences USA, 105, 1325213257.

Mannocci, L., Laran, S., Monestiez, P., Dorémus, G., Van Canneyt, O., Watremez, P. \& Ridoux, V. (2013) Predicting top predator habitats in the Southwest Indian Ocean. Ecography, 37, 261-278.

Mantua, N.J. \& Hare, S.R. (2002) The Pacific decadal oscillation. Journal of Oceanography, 58, 35-44.

Maury, M.F. (1852) Whale chart of the world. Hydrographical Office, Washington, DC, USA.

Mayo, C.A. \& Marx, M.K. (1990) Surface foraging behaviour of the North Atlantic right whale, Eubalaena glacialis, and associated zooplankton characteristics. Canadian Journal of Zoology, 68, 2214-2220.

McLeod, B.A., Brown, M.W., Moore, M.J., Stevens, W., Barkham, S.H. \& White, B.N. (2008) Bowhead whales, and not right whales, were the primary target of 16 th- to 17 thcentury Basque whalers in the western North Atlantic. Arctic, 61, 61-75. 
Mellinger, D.K., Nieukirk, S.L., Klinck, K., Klinck, H., Dziak, R.P., Clapham, P.J. \& Brandsdóttir, B. (2011) Confirmation of right whales near a nineteenth-century whaling ground east of southern Greenland. Biology Letters, 7, 411413.

Murison, L.D. \& Gaskin, D.E. (1989) The distribution of right whales and Zooplankton in the Bay of Fundy, Canada. Canadian Journal of Zoology, 67, 1411-1420.

Nemoto, T. (1970) Feeding patterns of baleen whales in the ocean. Marine food chains (ed. by J.H. Steele), pp. 241-252. University of California Press, Oakland, CA, USA.

Nicholls, N. (2008) Recent trends in the seasonal and temporal behaviour of the El Niño-Southern Oscillation. Geophysical Research Letters, 35, L19703.

NOAA-NEFSC (2013) Available at: http://www.nefsc.noaa.gov/psb/surveys/ (accessed 19 June 2013).

Norberg, J. \& DeAngelis, D. (1997) Temperature effects on stocks and stability of a phytoplankton-zooplankton model and the dependence on light and nutrients. Ecological Modelling, 95, 75-86.

Notarbartolo-Di-Sciara, G., Zanardelli, M., Jahoda, M., Panigada, S. \& Airoldi, S. (2003) The fin whale Balaenoptera physalus (L. 1758) in the Mediterranean Sea. Mammal Review, 33, 105-150.

Omura, H. (1986) History of right whale catches in the waters around Japan. Reports of the International Whaling Commission, Special Issue 10, 34-41.

Palacios, D., Baumgartner, M., Laidre, K. \& Gregr, E. (2013) Beyond correlation: integrating environmentally and behaviourally mediated processes in models of marine mammal distributions. Endangered Species Research, 22, 191-203.

Pauly, D. (1995) Anecdotes and the shifting baseline syndrome of fisheries. Trends in Ecology and Evolution, 10, 430.

Pearce, J. \& Ferrier, S. (2000) Evaluating the predictive performance of habitat models developed using logistic regression. Ecological Modelling, 133, 225-245.

Peterson, A.T. \& Vieglais, D.A. (2001) Predicting species invasions using ecological niche modeling: new approaches from bioinformatics attack a pressing problem. BioScience, 51, 363-371.

Peterson, A.T., Soberon, J., Pearson, R.G., Anderson, R.P., Martinez-Meyer, E., Nakamura, M. \& Araujo, M.B. (2011) Ecological niches and geographic distributions. Princeton University Press, Princeton, NJ and Oxford.

Pettis, H. (2013) North Atlantic right whale consortium 2013 annual report card. Report to the North Atlantic Right Whale Consortium, November 2013.

R Development Core Team (2013) R: a language and environment for statistical computing. $\mathrm{R}$ Foundation for Statistical Computing, Vienna, Austria.

Randin, C.F., Dirnböck, T., Dullinger, S., Zimmermann, N.E., Zappa, M. \& Guisan, A. (2006) Are niche-based species distribution models transferable in space? Journal of Biogeography, 33, 1689-1703.
Raxworthy, C.J., Martinez-Meyer, E., Horning, N., Nussbaum, R.A., Schneider, G.E., Ortega-Huerta, M.A. \& Peterson, A.T. (2003) Predicting distributions of known and unknown reptile species in Madagascar. Nature, 426, 837841.

Reeves, R.R. \& Mitchell, E. (1986) American pelagic whaling for right whales in the North Atlantic. Report of the International Whaling Commission, Special Issue 10, 221254.

Reeves, R.R., Mitchell, E.D., Mansfield, A. \& McLaughlin, M. (1983) Distribution and migration of the bowhead whale, Balaena mysticetus, in the Eastern North American Arctic. Arctic, 36, 5-64.

Reeves, R.R., Breiwick, J.M. \& Mitchell, E.D. (1999) History of whaling and estimated kill of right whales, Balaena glacialis, in the Northeastern United States, 1620-1924. Marine Fisheries Review, 61, 1-36.

Reeves, R.R., Smith, T.D., Webb, R.L., Robbins, J. \& Clapham, P.J. (2002) Humpback and fin whaling in the Gulf of Maine from 1800 to 1918. Marine Fisheries Review, 64, 112.

Reeves, R.R., Smith, T.M. \& Josephson, E.A. (2007) Nearannihilation of a species: right whaling in the North Atlantic. The urban whale: North Atlantic right whales at the crossroads (ed. by S.D. Kraus and R.M. Rolland), pp. 39-74. Harvard University Press, Cambridge, MA, USA.

Reilly, S.B., Bannister, J.L., Best, P.B., Brown, M., Brownell, R. Jr, Butterworth, D.S., Clapham, P.J., Cooke, J., Donovan, G., Urban, J. \& Zerbini, A.N. (2012) Eubalaena glacialis. The IUCN red list of threatened species. Version 2014.3. Available at: www.iucnredlist.org (accessed 2 January 2015).

Rice, D.W. (1998) Marine mammals of the world?: systematics and distribution. Society for Marine Mammalogy, Special Publication 4.

Romero, A. (2012) When whales became mammals: the scientific journey of cetaceans from fish to mammals in the history of science. New approaches to the study of marine mammals (ed. by A. Romero and E.O. Keith), pp. 3-30. InTech, Rijeka, Croatia.

Rondinini, C., Wilson, K.A., Boitani, L., Grantham, H. \& Possingham, H.P. (2006) Tradeoffs of different types of species occurrence data for use in systematic conservation planning: species data for conservation planning. Ecology Letters, 9, 1136-1145.

Rosenbaum, H.C., Brownell, R.L., Brown, M.W., Schaeff, C., Portway, V., White, B.N., Malik, S., Pastene, L.A., Patenaude, N.J. \& Baker, C.S. (2000a) World-wide genetic differentiation of Eubalaena: questioning the number of right whale species. Molecular Ecology, 9, 1793-1802.

Rosenbaum, H.C., Egan, M.G., Clapham, P.J., Brownell, R.L., Malik, S., Brown, M.W., White, B.N., Walsh, P. \& Desalle, R. (2000b) Utility of North Atlantic right whale museum specimens for assessing changes in genetic diversity. Conservation Biology, 14, 1837-1842. 
Rutherford, S., D’Hondt, S. \& Prell, W. (1999) Environmental controls on the geographic distribution of zooplankton diversity. Nature, 400, 749-753.

Sasaki, T., Nikaido, M., Hamilton, H., Goto, M., Kato, H., Kanda, N., Pastene, L., Cao, Y., Fordyce, R., Hasegawa, M. \& Okada, N. (2005) Mitochondrial phylogenetics and evolution of mysticete whales. Systematic Biology, 54, 77-90.

Sinclair, S.J., White, M.D. \& Newell, G.R. (2010) How useful are species distribution models for managing biodiversity under future climates. Ecology and Society, 15, 8.

Smith, T.D., Barthelmess, K. \& Reeves, R.R. (2006) Using historical records to relocate a long-forgotten summer feeding ground of North Atlantic right whales. Marine Mammal Science, 22, 723-734.

Smith, T.D., Reeves, R.R., Josephson, E.A. \& Lund, J.N. (2012) Spatial and seasonal distribution of American whaling and whales in the age of sail. PLoS ONE, 7, e34905.

Thompson, D.W. (1918) On whales landed at the Scottish whaling stations, especially during the years 1908-1914. Part I. The Northcaper. The Scottish Naturalist, 81, 197-208.

Thuiller, W., Lavorel, S., Araújo, M.B., Sykes, M.T. \& Prentice, I.C. (2005) Climate change threats to plant diversity in Europe. Proceedings of the National Academy of Sciences USA, 102, 8245-8250.

Torres, L.G., Smith, T.D., Sutton, P., MacDiarmid, A., Bannister, J. \& Miyashita, T. (2013) From exploitation to conservation: habitat models using whaling data predict distribution patterns and threat exposure of an endangered whale. Diversity and Distributions, 19, 1138-1152.

Townsend, C.H. (1935) The distribution of certain whales as shown by logbook records of American whale ships. Zoologica, 19, 1-50.

Whitt, A., Dudzinski, K. \& Laliberté, J. (2013) North Atlantic right whale distribution and seasonal occurrence in nearshore waters off New Jersey, USA, and implications for management. Endangered Species Research, 20, 59-69.

Wiens, J.J., Ackerly, D.D., Allen, A.P., Anacker, B.L., Buckley, L.B., Cornell, H.V., Damschen, E.I., Jonathan Davies, T., Grytnes, J.-A., Harrison, S.P., Hawkins, B.A., Holt, R.D., McCain, C.M. \& Stephens, P.R. (2010) Niche conservatism as an emerging principle in ecology and conservation biology: niche conservatism, ecology, and conservation. Ecology Letters, 13, 1310-1324.

Wikgren, B., KitePowell, H. \& Kraus, S. (2014) Modeling the distribution of the North Atlantic right whale Eubalaena glacialis off coastal Maine by areal co-kriging. Endangered Species Research, 24, 21-31.

Winn, H.E., Price, C.A. \& Sorensen, P.W. (1986) The distributional biology of the right whale (Eubalaena glacialis) in the western North Atlantic. Reports of the International Whaling Commission, Special Issue 10, 129-138.

Woodward, B.L., Winn, J.P. \& Fish, F.E. (2006) Morphological specializations of baleen whales associated with hydro- dynamic performance and ecological niche. Journal of Morphology, 267, 1284-1294.

Zurell, D., Jeltsch, F., Dormann, C.F. \& Schröder, B. (2009) Static species distribution models in dynamically changing systems: how good can predictions really be? Ecography, 32, 733-744.

\section{SUPPORTING INFORMATION}

Additional Supporting Information may be found in the online version of this article:

Figure S1 Fitted functions showing the species-environment relationships produced by the BRT.

Figure S2 Environmental suitability for right whales in summer predicted by the GAM in the North Pacific (A) and the North Atlantic (B).

Figure S3 Historical (pre-1950) records of North Atlantic right whale (Eubalaena glacialis) in the summer months (June to September).

Figure S4 Recent (post-1950) records of North Atlantic right whale (Eubalaena glacialis) in the summer months (June to September), outside its main known summer grounds.

Figure S5 Historical (pre-1950) and recent (post 1950) records of North Atlantic right whale (Eubalaena glacialis) in the summer months, according to date.

Table S1 Environmental predictors used in the species distribution models.

Table S2 Historical (pre 1950) records of North Atlantic right whale (Eubalaena glacialis) in the summer months (June to September).

Table S3 Recent (post 1950) records of North Atlantic right whale (Eubalaena glacialis) in the summer months (June to September).

Table S4 Region-by-region overview of the levels of agreement between the model's predictions for the summer distribution of the North Atlantic right whale (Fig. 2b) and locations of known summer records for this species, both historical (Figs 2c and S3, Table S2) and recent (Figs 2c and S4, Table S3)

Appendix S1 Historical records of North Pacific right whales.

Appendix S2 Environmental data.

Appendix S3 Species distribution models.

Appendix S4 Complementary analyses.

Appendix S5 Historical records of North Atlantic Right Whale.

Appendix S6 Extended discussion.. 


\section{BIOSKETCH}

Sophie Monsarrat is a PhD student interested in characterizing the impact of historical exploitation on the distribution and abundance of marine mammals at the global scale. She combines statistical models with historical data to understand species' historical distribution and abundance and inform current conservation practices. This $\mathrm{PhD}$ is part of the ANR MORSE project (www.cefe.cnrs.fr/morse), in which all co-authors participate, which aims at integrating an historical perspective in our perception of past human impact, projections of future changes and recommendations for the conservation and management of marine mammal populations.

Author contributions: S.M. and A.S.L.R. conceived the idea; T.D.S. and R.R.R. coordinated the collection of historical records of North Pacific right whales; A.S.L.R., S.M. and R.R.R. reviewed historical records of North Atlantic right whales; S.M., M.G.P., C.N.M. and D.M.K. analysed the data; and S.M. and A.S.L.R. led the writing. All authors discussed the results and commented on the manuscript.

Editor: Janet Franklin 